\title{
Entrepreneurship, Economic Growth and Entrepreneurship Theories
}

\section{Dr Wilhelmina Smith}

\author{
Department of Business Management, University of Fort Hare \\ University of Fort Hare, Alice, P.B. X1314, Eastern Cape, 5700, South Africa \\ Email: wsmith@ufh.ac.za \\ Mr Tendai Chimucheka \\ Department of Business Management, University of Fort Hare \\ University of Fort Hare, Alice, P.B. X1314, Eastern Cape, 5700, South Africa \\ Email: tchimucheka@ufh.ac.za; tenchims@gmail.com
}

Doi:10.5901/mjss.2014.v5n14p160

\begin{abstract}
This study discusses entrepreneurship, economic growth and entrepreneurship theories. Economic theories of entrepreneurship are explained in this study. Theories of entrepreneurship are used to link entrepreneurship to economic growth. Entrepreneurial ventures are also differentiated from ordinary small businesses, and entrepreneurship as a discipline is explained in a way that shows how it differs from management in general.
\end{abstract}

Keywords: entrepreneurship, economic growth, theory, skills, opportunity

\section{Introduction}

Entrepreneurship is very crucial to any economy. Worldwide, entrepreneurship is regarded as the economic engine necessary for economic growth, poverty alleviation and reduction, and also job creation. There is no doubt that a relationship exists between entrepreneurship levels and the economic growth of any nation.

The objectives of this study are to discuss entrepreneurship, outline the differences between entrepreneurs and small business owners, outline the differences between entrepreneurship and management and to explain the role of entrepreneurs in the economy. This study also seeks to explain the relationship between entrepreneurship and economic growth, suggest how entrepreneurs can turn skills into opportunities and discuss the economic theories of entrepreneurship.

Only secondary data is used in this study for it is purely a literature study. Information was gathered from various but credible literature sources in the field of entrepreneurship.

\section{Entrepreneurship}

Richard Cantillon developed one of the early theories of entrepreneurship in 1725 focused on the individual involved in an enterprise. He defined the entrepreneur as an individual who assumes risk, by buying at a certain price and selling at an uncertain price. At the time of the industrial revolution (1830), Jean Baptiste Say expanded the definition of an entrepreneur to include the possession of managerial skills. Say believed that an entrepreneur was able to coordinate and combine the factors of production. Later on, Joseph Schumpeter (1883-1950) also made a contribution to the discussion on entrepreneurship. Schumpeter introduced the concepts of new combinations which involve a change in product or process that existed for as long as the introduction of new combination of inputs was under way. Resultantly, Schumpeter described an entrepreneur as an innovator.

In modern times, an entrepreneur can be defined as a person who sees an opportunity in the market, gathers resources, establishes and grows a business towards the satisfaction of the needs of the market (Nieman \& Pretorius, 2004:4). According to Nieman (2001:58), an entrepreneur usually endures the risks of the venture, and reaps his/her reward which is profit attained if the business succeeds.

An entrepreneur is also regarded as an economic agent who is able to perceive market opportunities and assembles the needed factors of production in order to exploit specific opportunities (Van Aardt et al., 2008:4). Such 
entrepreneurs are people who are considered to be heroes of free enterprise for they grow businesses through innovation and creativity (Van Aardt et al., 2008:5). It is a verity that all entrepreneurs want their businesses to grow (Nieman and Pretorius, 2004:4).

According to Zimmerer and Scaborough (2008:5), "an entrepreneur is a person who creates a new business in the face of risk and uncertainty for the purpose of achieving growth and profit by identifying significant opportunities and assembling the necessary resources to capitalise on them". It can thus be accepted that entrepreneurs do not only come up with ideas, they act on them.

Entrepreneurs also possess particular characteristics that set them apart from ordinary people (Nieuwenhuizen, 2004:40) This however does not mean that they have the same characteristics. Van Aardt et al., (2008:9) and Nieman and Nieuwenhuizen (2009:32); identified that such individuals have a desire to achieve, they are hard workers who nurture quality, are excellence oriented, money oriented, accepting responsibility, reward oriented, optimistic, good organisers and are passionate about business. Other characteristics include locus of control, creativity and innovation, determination and persistence, need for independence, need for achievement and risk taking.

Longenecker, Moore, Petty and Palich (2006:16) also identified commitment and determination, leadership, opportunity obsession, tolerance of risk, creativity, self reliance and adaptability, and motivation to excel as other characteristics of entrepreneurs. It is thus obvious that these characteristics can be developed and improved through entrepreneurship education and training (Botha, Nieman \& Van Vuuren, 2006:2).

\section{Entrepreneurship Defined}

Van Aardt et al., (2008) define entrepreneurship as the act of initiating, creating, building and expanding an enterprise or organisation, as well as building an entrepreneurial team and gathering other resources to exploit an opportunity in the marketplace for long term growth. Timmons and Spinelli (2007) suggest that entrepreneurship is a way of thinking, reasoning and acting which is opportunity obsessed, holistic in approach, and leadership balanced. Rwigema and Venter (2004:6) propose entrepreneurship to be the process of conceptualising, organising, launching and through innovation, nurturing a business opportunity into a potentially high growth venture in a complex and unstable environment.

Burger et al., (2005:80), and Zimmerer and Scarborough, (2008:5) mention that entrepreneurship can be defined as the creation of new businesses in conditions of risk and uncertainty in order to make a profit. Entrepreneurship can be described as the result of a systematic and disciplined process of applying innovation and creativity to opportunities and needs in the market (Zimmerer and Scarborough, 2008:44). According to above authors, it involves the application of focused strategies to new ideas and new insights to create a product or a service that can either satisfy people's needs or solve their problems.

It also comes to light that growth of businesses is a defining feature of entrepreneurial ventures (Nieman \& Pretorius, 2004:4; Rwigema \& Venter, 2004:5). Also important as defining features of entrepreneurship are risk taking and innovation. It is evident from the multitude of definitions, that entrepreneurship involves people who engage in some type of behaviour.

\section{Entrepreneurs Versus Small Business Owners}

It is very important to distinguish between entrepreneurial ventures and ordinary small businesses. According to Nieman and Pretorius (2004:4), ordinary small businesses are not dominant in their fields and they rarely engage in any innovative or new practices. On the other hand, entrepreneurial ventures can be described as those businesses that have profitability and growth set as principal objectives.

Key distinguishing characteristics between entrepreneurial ventures and small businesses include innovation, potential for growth, and strategic objectives, which are discussed separately.

\subsection{Innovation}

Zimmerer and Scarborough (2008:43) define innovation as the ability to apply creative solutions to problems and opportunities to enhance the lives of people. In this case, creativity is described as the ability to develop new ideas and to discover new ways of looking at opportunities and problems. Entrepreneurial ventures thrive on innovation, meaning that this concept can refer to technological innovation, a new product or a new way of producing it, of offering a service, of marketing, distributing or structuring and managing the organisation (Nieman \& Pretorius, 2004:6). In contrast, many small businesses are usually involved only in delivering an established product or service. 


\subsection{Potential for growth}

Due to their innovative approach, an entrepreneurial business has more potential for growth than a small business. Entrepreneurial ventures are not limited to existing markets; they can create their own markets (Nieman \& Pretorius, 2004:6). The small business on the other hand, operates in an established industry and is unique only in terms of its locality, only operating within a specific market.

\subsection{Strategic objectives}

Nieman and Pretorius (2004:6) state that entrepreneurial ventures usually set strategic objectives in relation to growth targets, market segmentation, market share and market position. Small businesses do not really care about the stated objectives. The objectives of a small business rarely go beyond survival, profit and sales targets (Nieman \& Pretorius, 2004:6), which can be seen as a management aspect.

\subsection{Entrepreneurship and management}

Although not all entrepreneurs are good managers or leaders, management and leadership skills are important success factors for entrepreneurs. The same can be said also to managers that they are not necessarily entrepreneurs, or even entrepreneurially oriented (Nieman \& Nieuwenhuizen, 2009:13).

There are differences between entrepreneurial and managerial functions, as well as the expertise and competence required by each individual (Nieman \& Nieuwenhuizen, 2009:13). Entrepreneurial functions include the following among others:

- innovative thinking and the identification of opportunities;

- planning and establishment and /or growth of the business; and

- application of resources.

The management functions on the other hand include planning, organising, leading and controlling.

The entrepreneur also has to manage the various business functions such as finance, marketing, production, purchasing, administration, human resources and public relations. Entrepreneurs often have the ability to identify opportunities and establish the business. They also need some education or training to be able to manage their businesses successfully.

It is important to note that to be effective, entrepreneurs need to possess the skills of both the entrepreneur and of the professional manager (Van Aardt et al., 2008:8). The table below shows the important success factors as identified by Nieman and Nieuwenhuizen (2009) for both entrepreneurs and managers.

Table 1: Success factors of entrepreneurs and managers

\begin{tabular}{|l|l|}
\hline Success factors of entrepreneurs & Managerial success factors \\
\hline - creativity and innovation; & - planning; \\
- risk orientation; & - knowledge of competitors; \\
- leadership; & - mainly market oriented; \\
- good human relations; & positive attitude \\
- perseverance & - high quality work enjoys priority; \\
- commitment & - knancial insight and management; \\
\hline
\end{tabular}

Source: Adapted from Nieman and Nieuwenhuizen (2009:14-19)

The difference of these success factors entails that entrepreneurs do it themselves and they work to achieve their goals, whereas managers work to achieve the objectives of others (such as shareholders) and they need expertise to do so.

\subsection{The role of entrepreneurs}

It can be said that entrepreneurship is the spark that brings other factors of production into motion (Du Toit et al., 
2009:43). It is very important to note that entrepreneurship is mobilised by confidence, skills, creativity and expectations of individuals. According to Du Toit et al., (2009:43), it is people with entrepreneurial skills and talents and knowledge that are able to achieve more than others, especially when it comes to mobilising productive resources and starting enterprises that have the potential to grow. These people with entrepreneurial skills and knowledge are rare and valuable to the society.

Jennings (1994:37) mentioned six functional roles of the entrepreneur in economic thought. He identified the functional roles of the entrepreneur and the contributing theorist. Table 2 shows the functional roles of the entrepreneurs as described by Jennings.

Table 2: The functional roles of the entrepreneur

\begin{tabular}{|c|c|}
\hline Functional role & Theorist \\
\hline Speculator & Richard Cantillon \\
\hline Coordinator & Jean-Baptiste Say \\
\hline Product owner & Frederick Hawler \\
\hline Innovator & Joseph Schumpeter \\
\hline Decision maker & Frank Knight \\
\hline Arbitrator & Israel Kirzner \\
\hline
\end{tabular}

Source: Barreira et al., 2008:66

From Table 2, it can be noted that the roles of entrepreneurs as speculators, coordinators of resources, product owners, arbitrators, innovators as well as decision makers. These roles can be seen as complementing one another and individuals need to be equipped with the necessary skills in order to be able to carry out these roles effectively.

Besides stipulating the functional roles of entrepreneurs, Jennings (1994:63) also described entrepreneurial functions as described by early economists. Table 3 shows the summary of entrepreneurial functions.

Table 3: Entrepreneurial functions

\begin{tabular}{|l|l|}
\hline \multicolumn{1}{|c|}{ Economist } & \multicolumn{1}{c|}{ Concept of entrepreneurial function } \\
\hline Francis Edgeworth & Being a coordinator and middleman who never disappears, even in general equilibrium. \\
\hline Alfred Marshall & $\begin{array}{l}\text { Being a business leader and head of the firm-innovating, coordinating, responding to profit signals, and } \\
\text { bearing risk. }\end{array}$ \\
\hline Frederick Hawley & $\begin{array}{l}\text { Being an owner or enterpriser who makes decisions regarding what product or service is to be produced } \\
\text { and is also the bearer of uncertainty. }\end{array}$ \\
\hline John Bates Clark & Not being an uncertainty bearer but an arbitrageur who shifts resources toward their most profitable uses \\
\hline Irving Fisher & $\begin{array}{l}\text { Being a bearer of uncertainty who reduces the randomness of uncertainty by making forecasts and } \\
\text { deciding what to do based on subjective speculation. His role as a profit receiver makes him an important } \\
\text { and distinct economic agent. }\end{array}$ \\
\hline Frank Knight & $\begin{array}{l}\text { Being a decision maker in an uncertain environment. In that role he determines consumer's wants and } \\
\text { secures various services and materials to produce the product or service. Profits received are not for } \\
\text { dealing with uncertainty-based differences between the anticipated value of resource services and their } \\
\text { actual value. }\end{array}$ \\
\hline Joseph Schumpeter & $\begin{array}{l}\text { Being an innovator who carries out new combinations of economic development, which are new goods, a } \\
\text { new method of production, new markets, new sources of raw materials, or a new organisational form. }\end{array}$ \\
\hline
\end{tabular}

Source: Jennings, 1994:63

The description in table 3 , details the functions of the entrepreneur in an uncertain environment. According to Barreira et al., (2008:68), the entrepreneur develops from a bearer of uncertainty, to an arbitrageur who was described by Investopedia (2011) as a type of an investor who attempts to profit from price inefficiencies in the market by making simultaneous trades that offset each other and capturing risk-free profits. An entrepreneur further develops to be a speculator, and finally an innovator as described in Schumpeter's theory which is explained in section 3.5.

In South Africa, entrepreneurs play a critical role in creating employment, providing goods and services and also aiding large firms. They also contribute to the Gross Domestic Product (GDP) of South Africa. Most entrepreneurs 
operate SMMEs in South Africa. SMMEs form $97,5 \%$ of all businesses in South Africa, employ around $55 \%$ of all formal private sector employees, and generate 35\% of the GDP (Du Toit et al., 2009:43).

According to Ekpe (2011:287) entrepreneurs play certain roles so as to complement the government's efforts in the development of the SMME sector. The roles of entrepreneurs identified by Ekpe (2011:287) include making good business decisions, having the right motive, making an effort to acquire appropriate education, training, business experience, skills, innovation, market information and also social networks. Fulfilling the above mentioned roles adequately, it should surely contribute towards the success of such entrepreneurial ventures and ultimately contribute towards economic growth.

\section{Entrepreneurship and Economic Growth}

It is voiced that entrepreneurship plays an important role in economic processes, but its study has been marginalised through the dominance of neo-classical economics, which has all but assumed the entrepreneur out of existence (Barreira, Dhliwayo, Luiz, Naude \& Urban, 2008:63).

It is accepted everywhere in the world that entrepreneurship is one of the most important solutions, not only to low economic growth, but also to unemployment and poverty (Botha, Nieman \& Van Vuuren, 2006:2; Ekpe, 2011:287). According to Nieman and Pretorius (2004:4), entrepreneurial ventures create employment and economic growth for any nation. The creation of new ventures and the growth of existing businesses are vital contributing factors to any economy (Botha, Nieman \& Van Vuuren, 2006:2).

Entrepreneurial firms also create important spill-overs that affect regional employment rates in the long term, there is diverse empirical evidence showing the impact of entrepreneurship on economic growth (Barreira, 2008:63-71).

Subsequently, entrepreneurship education is one way of enhancing entrepreneurial activity (Botha, Nieman \& Van Vuuren, 2006:2).

\section{Turning Skills into Opportunities}

Entrepreneurial attributes such as the motive for venturing into business, obtaining business and innovative skills, having educational and networking ability, are also vital elements to consider in entrepreneurial success that can contribute to economic growth (Ekpe, 2011:288), which means that these entrepreneurial skills need to be developed if the entrepreneurs are to be successful. It is important to note that entrepreneurial skills are not inherited and unchangeable as traditional thought may lead us to believe. Research has proved that people can still change certain characteristics of entrepreneurs which were previously regarded as genetic (Nieuwenhuizen, 2004:48).

When assessing themselves, entrepreneurs need to do a self-introspection and self-evaluation to be able to establish their personal strengths and weaknesses. Individual strengths can then be positively applied towards the success of the business, while the weaknesses could be addressed through entrepreneurship education and training.

Although it has been noted that skills differ, an entrepreneur must be committed to developing both entrepreneurship and management skills (Nieuwenhuizen, 2004:38). This is mainly because both entrepreneurial and managerial skills are crucial for entrepreneurial success. It can thus be taken that entrepreneurial skills are related to the personal and interpersonal competencies of people and are generally expressed in their behaviour. Management skills on the other hand are an indication of how well an entrepreneur can perform important tasks and activities related to the functions of a business.

According to Nieuwenhuizen (2004:49), it is important to take note that developing entrepreneurial skills alone while neglecting business skills, will not ensure optimal results. It is a combination of both entrepreneurial skills and business training in entrepreneurship education that will be most effective in developing and preparing successful entrepreneurs.

\section{Theories of Entrepreneurship}

Different views exist on what exactly entrepreneurship or an entrepreneur is. Economists subscribe to the view that entrepreneurs combine different resources in specific combinations to generate products and services at a profit (Du Toit et al., 2009:41). Their focus is on what entrepreneurs do, and to them, are people who are driven primarily by the profit motive. Behaviourists describe entrepreneurs according to their characteristics, for example their achievement orientation, their propensity towards creativity and risk taking. Marxists regard entrepreneurs as exploiters. According to Du Toit et al., (2009), corporate managers see entrepreneurs as small operators who lack the potential to manage a large 
enterprise. Proponents of a market economy see entrepreneurs as the economic force responsible for the prosperity of a country (Du Toit et al., 2009:41).

There are different schools of thought to entrepreneurship theories. However, to explain the role of entrepreneurship in economic growth, the researchers use economic theories of entrepreneurship. The theories to be used include Leibenstein's X-efficiency theory, the Hayek and Kirzner theory on the market process, the Knight on the role of uncertainty and Schumpeter's theory on innovation.

\subsection{Leibenstein’s X-efficiency (1978)}

Leibenstein's theory describes essential characteristics of the environment in which the entrepreneur operates (Casson, 1982:364). According to Leibenstein, in the world of the entrepreneur, it is inefficiency which is the normal state of affairs. $X$-efficiency is defined as the degree of efficiency maintained by individuals and firms under conditions of imperfect competition (Investopedia, 2011) X-efficiency arises either because the firm's resources are used in a wrong way or because they are wasted. Leibenstein regarded entrepreneurship as a creative response to X-efficiency. He also believed that individuals have different attitudes and hence different behaviours.

Investopedia (2011) mentions that in neo-classical economics, under perfect competition, individuals and firms should maximise efficiency in order to succeed and make profits. Firms that will not maximise efficiency will fail or can be forced to exit the market.

The X-efficiency theory asserts that under conditions of less-than-perfect competition, inefficiency may persist (Investopedia, 2011). This theory is controversial for the fact that it conflicts with the assumption of utility-maximising behaviour which is an axiom well accepted in the economic theory. According to Investopedia (2011) some economists argue that the concept of $x$-efficiency is merely the observance of workers' utility-maximising trade-off between effort and leisure.

Harvey Leibenstein's (in Binks \& Vale, 1990) observations in 1968 suggest that a successful entrepreneur needs to synchronise inputs from several different markets which imply that two types of entrepreneurs can be identified. The first type refers to Schumpeter's entrepreneur, who arranges new combinations, while the second type refers to an entrepreneur who performs managerial functions by establishing or organising traditional combinations.

\subsection{Hayek and Kirzner on the market process (1948)}

Hayek visualises a world in which there is a continuous process of discovery; mainly minor discoveries about individual wants at particular times and places. According to Hayek, these discoveries are localised, so that different people have access to different information.

For Kirzner, the adjustment of price is the main role of the entrepreneur. According to Kirzner, alertness to disequilibrium is the distinguishing characteristic of the entrepreneur. He defined the entrepreneur as anyone who is alert to profitable opportunities for exchange (Deakins \& Freel, 2009:4).

The Kirznerian entrepreneurs are alert to opportunities for trade and they play an intermediary role and make profit. These possibilities of making profits exist because of imperfect knowledge. According to Kirzner, entrepreneurs have some additional knowledge which is not generally possessed by others, and this allows them to take advantage of profitable opportunities as they arise (Deakins \& Freel, 2009:4).

Information in the market place is crucial for the Kirznerian entrepreneur (Deakins \& Freel, 2009:4). It is the possession of additional knowledge that provides opportunities for creative discoveries. This is in contrast to the Schumpeterian view where anyone could potentially possess the additional knowledge and be alert to the business opportunities.

\subsection{Knight on the role of uncertainty (1921)}

Knight identifies the entrepreneur as the recipient of profit. He identified profit as the reward to the entrepreneur for bearing costs for uncertainty. He emphasised the speculative nature of entrepreneurship.

Knight's view of an entrepreneur is close to the commonly held view of the entrepreneur as a calculated risk taker (Deakins \& Freel, 2009:6). For Knight an entrepreneur is an individual who is prepared to undertake risk and reap the reward. According to Deakins and Freel (2009:4), the reward for bearing uninsurable risk and uncertainty is the profit that will be earned by the entrepreneur.

The opportunity for profit arises out of uncertainty surrounding change. If change is perfectly predictable, then no 
opportunity for profit would exist (Deakins \& Freel, 2009:6). The entrepreneur is an individual who is prepared to undertake risk in an uncertain world.

According to Deakins and Freel (2009:6), Knight distinguished between risk and uncertainty. Risk happens when one have certain predictable outcomes. The outcomes should be predicted with a certain degree of profitability. On the other hand, uncertainty arises when the probability of outcomes cannot be calculated.

Knight acknowledged the importance of management skills to entrepreneurs. According to Deakins and Freel (2009:6), one of the characteristics of entrepreneurs (following Knight) could be of taking the responsibility for one's own actions.

We can safely say that the Knightian entrepreneur is anyone who is prepared to undertake the risk of setting up their own business. The problem with this theory is that any risk taker can be termed an entrepreneur (Deakins \& Freel, 2009:7). Subsequently, the entrepreneur is anyone who has the confidence and venturesome enough to make judgements about the uncertain future and reward for this is profits that will be earned.

\subsection{Schumpeter on innovation (1934)}

Schumpeter offers a much more far-reaching view of entrepreneurship than any other theories do. According to Schumpeter, the entrepreneur is the prime mover in economic development, and his/her function is to innovate or carry out new innovations. He identified the entrepreneur as a force to economic change who brings creative destruction to the economy by revolutionising the production processes with newer and more efficient ones. Unlike Kirzner's entrepreneur, Schumpeter's entrepreneur is a special person for he/she is an innovator and one who brings about change through the introduction of new technological processes or products (Deakins \& Freel, 2009:4).

For Kirzner, anyone has the potential to be an entrepreneur and he / she operates within set production constraints. This is not the same for Schumpeter. Schumpeter believed that only certain extra ordinary people have the ability to be entrepreneurs and they bring about extra ordinary events (Deakins \& Freel, 2009:4). According to Schumpeter, an entrepreneur changes technological possibilities, alters convention through innovative activity and hence, moves production constraints. A Schumpeterian entrepreneur develops new technology, whereas the Kirznerian entrepreneur operates on opportunities that arise out of new technology.

In the Schumpeterian view, it is an entrepreneur who is the catalyst for economic change, which is voiced by the caption below.

"The process of creative destruction, in which entrepreneurs create new ideas and new businesses that make existing ones absolute, is a sign of a vibrant economy (Zimmerer \& Scarborough, 2008:5).

Joseph Schumpeter, a prominent Australian economist, challenged various assumptions underlying neoclassical economics. Schumpeter saw the entrepreneur as the source of new demand through the process of innovation (Barreira et al., 2008:68).

It is entrepreneurs who play an important role by challenging the status quo, and enter the market using innovations (Barreira et al., 2008:68).

Ahwireng-Obeng (2006:190) and Barreira et al., (2008:68) are of the view that in Schumpeter's analysis, entrepreneurs innovate by carrying out one or more of the following activities:

- introducing new goods or a new quality of goods;

- introduction of new methods of production;

- opening up new markets;

- discovering new sources of supply of raw materials or semi-processed goods; and

- reorganising the structure of an industry, for example creating a monopoly or even breaking up an existing one.

\subsection{Shackle's theory}

According to Deakins and Freel (2009:7), Shackle's entrepreneur is one who is creative and imaginative. Unlike Kirzner's entrepreneur who perceives, Shackle's entrepreneur imagines opportunities, and everyone potentially has this creative ability that is excised in making choices. The role of uncertainty and imperfect information remains important for the view of the role of the entrepreneur by Shackle (Deakins \& Freel, 2009:7). It is uncertainty that gives rise to opportunities for certain individuals to imagine opportunities for profit.

Shackle's entrepreneur is creative and original (Deakins \& Freel, 2009:7). The act of imagination is important for 
identifying the potential of opportunities. This potential is compared to resources available, which can lead to the decision to produce, hence the act of entrepreneurship.

Shackle indicates that creativity is an important element in the entrepreneurial process, but how this creative process occurs, and the factors which may influence it, remain areas that are just beginning to be explored (Deakins \& Freel, 2009:7). Entrepreneurship education, among other factors may influence an individual's ability to be creative. Other factors include personal background, experiences and attitudes (Deakins \& Freel, 2009:7).

\subsection{Casson's Theory}

Casson attempts to synthesise some of these entrepreneurial attributes and concepts that were discussed by other major writers. Casson recognises that the entrepreneur will have different skills (Deakins \& Freel, 2009:7). It is skills and knowledge that enables the entrepreneur to make judgements, to coordinate scarce resources.

According to Casson, the entrepreneur makes judgemental decisions that involve the reallocation of resources. Casson emphasised that lack of capital may be a barrier for successful entrepreneurship. This is because entrepreneurs require command over resources if they are to back their judgements and decisions.

Casson's view is closer to that of Knight than for other writers (Deakins \& Freel, 2009:7) in that he also believes that an entrepreneur operates within a set of technological conditions, by making difficult judgemental decisions they are able to enjoy the reward of bearing risk. The desire for profit and the ability to judge enables the entrepreneur to coordinate demand and supply under uncertainty (Deakins \& Freel, 2009:7). According to Deakins and Freel (2009:7), Casson's insight is to view change as an accompaniment to entrepreneurship and it is the pace of change that provides opportunities.

\section{Conclusion}

This study explained entrepreneurship, economic growth and the theories of entrepreneurship. Entrepreneurship was defined and discussed; it was also differentiated from management. Entrepreneurs are differentiated from ordinary small business owners. This study also explained why entrepreneurs are important to any country. The role of entrepreneurs in economic growth was also given attention to. Economic theories of entrepreneurship were used to explain the role of entrepreneurs, the importance of entrepreneurship and why it is important to develop entrepreneurial skills of our citizens.

\section{References}

Binks, M and Vale, P. 1990. Entrepreneurship and economic change. London: McGraw-Hill.

Botha, M., Nieman, G.H and Van Vuuren, J.J. 2006. Evaluating the women entrepreneurship training programme: A South African Study. International Indigenous Journal of Entrepreneurship, Advancement, Strategy and Education.

Botha, M., Nieman, G.H and Van Vuuren, J.J. 2006. Evaluating the women entrepreneurship training programme: A South African Study. International Indigenous Journal of Entrepreneurship, Advancement, Strategy and Education.

Burger, L., O'Neill, C and Mahadea, D. 2005. The impact of previous knowledge and experience on the entrepreneurial attitudes of grade 12 learners. South African Journal of Education, 25(2):89-94.

Casson, M.C. 1982. The entrepreneur: an Economic Theory. Martin Robertson \& Co. Ltd.

Deakins, D and Freel, M. 2009. Entrepreneurship and small firms. $5^{\text {th }}$ Edition. New York: McGraw Hill.

Du Toit, G.S., Erasmus, B.J and Strydom, J.W. 2009. Introduction to Business Management. $7^{\text {th }}$ Edition. Oxford, Southern Africa.

Ekpe, I. 2011. Women entrepreneurs and economic development in Nigeria: Characteristics for success. International Journal of Business and Social Science 2(1):287-291.

Investopedia. 2011. (Online) Available: http://www.investopedia.com/terms/a/arbitrageur.asp\#axzz1kghGxjDh [Accessed 28 January 2012].

Jennings, D.F. 1994. Multiple perspectives of entrepreneurship. Cincinnati, Ohio: South Western Publishing Company.

Knight, F.H. 1964. Risk, uncertainty and profit. New York.

Longenecker, J.D., Moore, C.W., Petty, J.W and Palich, L.E. 2006. Small Business Management. An entrepreneurial emphasis. International edition. Thompson, South Western.

Nieman, G. 2001. Training entrepreneurs and small business enterprises in South Africa: A situational analysis. Education and Training, 43(8/9):445-450.

Nieman, G and Neuwenhuizen, C. 2009. Entrepreneurship: A South African Perspective. Pretoria: Van Schaik.

Nieman, G and Pretorius, M. 2004. Managing growth. A guide for entrepreneurs. Cape Town: Juta and Co. Ltd.

Nieuwenhuizen, C. 2004. Basics of entrepreneurship. Lansdowne, Cape Town: Juta \&Co. Ltd.

Rwigema, H and Venter, R. 2004. Advanced Entrepreneurship. Oxford University Press: Southern Africa. 
Timmons, J.A and Spinelli, S. 2007. New venture creation: entrepreneurship for the 21st century. Boston: McGraw Hill.

Van Aardt, I., Van Aardt, C., Bezuidenhout, S and MUMBA, M. 2008. Entrepreneurship and New Venture Management. $3^{\text {rd }}$ Edition. Oxford University Press: Southern Africa.

Zimmerer, T.W and Scarbourough, N.M. 2008. Essentials of entrepreneurship and small business management. Prentice Hall. 